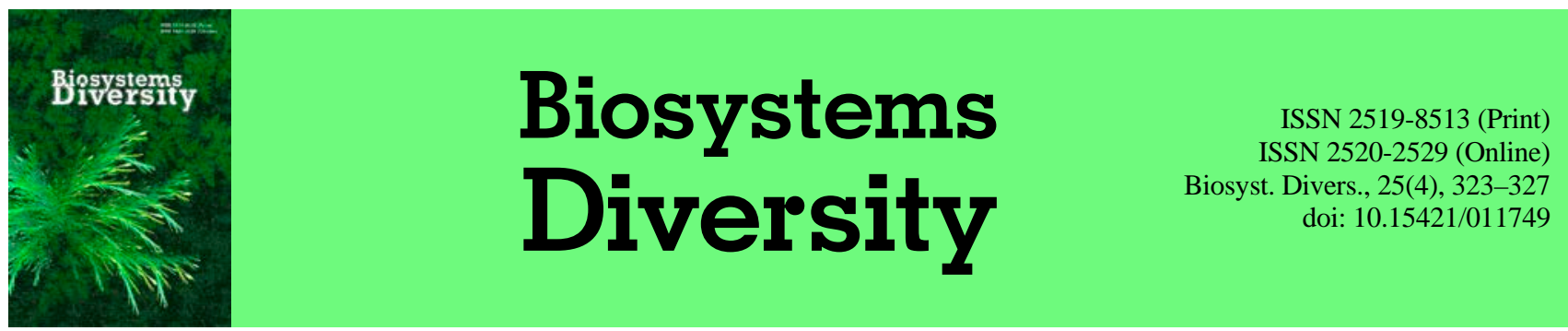

\title{
COXI based phylogenetic analysis of Caucasian clade of European Troglocaris (Crustacea: Decapoda: Atyidae) with the suggestion of a new taxonomic group structure
}

\author{
I. Marin \\ A. N. Severtzov Institute of Ecology and Evolution of RAS, Moscow, Russia \\ Altai State University, Barnaul, Russia
}

Article info

Received 19.10.2017

Received in revised form 11.11.2017

Accepted 15.11.2017

A. N. Severtzov Institute of Ecology and Evolution of RAS,

Leninsky prospect, 33,

Moscow, 119071, Russia.

Altai State University,

Leninsky Prospect, 61 ,

Barnaul, 656049, Russia.

Tel: +7-915-302-50-12

Email:

coralliodecapoda@mail.ru,

vanomarin@yahoo.com

Marin, I. (2017). COXI based phylogenetic analysis of Caucasian clade of European Troglocaris (Crustacea: Decapoda: Atyidae) with the suggestion of a new taxonomic group structure. Biosystems Diversity, 25(4), 323-327. doi:10.15421/011749

New genetic data on Caucasian troglobiotic shrimps collected from the territory of Russia, Abkhazia and Western Georgia are presented. Based on new genetic data on the marker region of subunit I of cytochrome oxidase of mitochondrial DNA (COXI mtDNA) of Caucasian species and other taxa of European cave shrimps (Troglocaris s.l.) from GenBank (NCBI) database, a new generic structure is presented. Based on a significant genetic divergence of COXI mtDNA subgenera of Troglocaris s.l., namely Troglocaris s.s., Xiphocaridinella and Spelaeocaris, should be considered as separate genera while Troglocaris (Troglocaridella) hercegovinensis (Babić, 1922) is suggested to be transferred within Dinaric genus Spelaeocaris as Spealeocaris hercegovinensis (Babić, 1922) comb. nov. Besides, Troglocaris bosnica shows a significant a genetic difference (at the level of the separate genus) from the remaining representatives of the genus Troglocaris s.s. Moreover, p-distances (COXI) of about $17 \%$ are supposed for generic separation within European Troglocaris-related atyid shrimps and 5\% for separation of cryptic species within Caucasian Xiphocaridinella. A list of all known taxa of Troglocaris-related atyid shrimps of the European part and a discussion of the general distribution of troglocaridid atyid shrimps in the Balkans and the Caucasus are presented. A new version of divergence events between Dinaric-Caucasian Troglocaris lineages (genera) based on new genetic data is suggested.

Keywords: phylogeny; COXI mtDNA; Xiphocaridinella; stygobiotic; stygobionts; shrimps; Caucasus

\section{Introduction}

Karst biocenoses due to their isolated location are especially rich in endemic species. It is very likely that each karst system has its own unique set of inhabiting species. One of the richest troglobiotic faunas in the world exists on the territory of the Southern Caucasus, followed by the cave and underground water fauna of the Balkan Peninsula. At the same time, the degree of study of the European hypogean communities obviously considerably exceeds that of the Caucasian ones. Troglobiotic higher crustaceans (Decapoda, Isopoda and Amphipoda) are the most important component of the hypogean cave ecosystems, sometimes forming them entirely. As a rule, in cave associations, crustaceans lead in number and diversity, forming the basis of the food pyramid of these communities. The relatively sparse data from the karst regions of the Caucasus indicate the extreme richness of the fauna of 37 troglobiotic crustaceans (about 50 endemic species in the Caucasus are known) (see review in Turbanov and Marin, 2015; Turbanov et al., 2016). At the moment, both the habitation of a larger number of species, and the wider distribution of this group in the Caucasus are assumed (e.g. Sadowsky, 1930; Birštein, 1939, 1948; Juzbaš’jan, 1940; Sendra and Reboleira, 2012; Marin and Sokolova, 2014; Marin, 2017; Turbanov et al., 2016). At the same time, subterranean fauna is characterized by a large number of endemics (local endemism), due to special ecological conditions and isolated location and low potential for dispersal (see Sket and Zakšek, 2009).

The European stygobiotic atyid shrimp genus Troglocaris Dormitzer, 1853 (Crustacea: Decapoda: Atyidae) is currently divided into 4 subgenera: Spelaeocaris Matjašič, 1956 (4 species), Troglo- caridella Babić, 1922 (1 species), Xiphocaridinella Sadowsky, 1930 (6 species) and Troglocaris s. str. (4 valid species and 6 subspecies) (Zakšek et al., 2006, 2009; Sket and Zakšek, 2009; Marin and Sokolova, 2014; Marin and Turbanov, 2015; Marin 2017; Marin and Sinelnikov, 2017). The main morphological peculiarity which distinguishes Troglocaris from other European atyid shrimps, such as Atyaephyra de Brito Capello, 1867, Dugastella Bouvier, 1912, Gallocaris Sket et Zakšek, 2009 and Typhlatya Creaser, 1936 (Sket and Zakšek, 2009) is the length of the subapical and apical spines on the appendix masculina in males, which are significantly smaller than the diameter of the appendix masculina in all representatives of the genus Troglocaris (see key in Sket and Zakšek, 2009). At present, the division into subgenera does not satisfy modern morphological requirements, since most of the considered morphological features vary greatly even within the species of the same subgenus (see, for example, the length of the rostrum within the subgenus of Xiphocaridinella (see Marin, 2017)) and such division is mainly supported by geographical distribution.

Order Decapoda Latreille, 1802

Family Atyidae De Haan, 1849

Subfamily Typhlatyinae Holthuis, 1986

Genus Troglocaris Dormitzer, 1853

Subgenus Troglocaris Dormitzer, 1853 - distributed exclusively in the Balkans Troglocaris (Troglocaris) anophthalmus (Kollar, 1848)

Troglocaris (Troglocaris) anophthalmus anophthalmus (Kollar, 1848) Troglocaris (Troglocaris) anophthalmus intermedia Babić, 1922

Troglocaris (Troglocaris) anophthalmus legovici Jugovic, Jalžić, Prevorčnik and Sket, 2012

Troglocaris (Troglocaris) anophthalmus ocellata Jugovic, Jalžić, Prevorčnik and Sket, 2012 
Troglocaris (Troglocaris) anophthalmus periadriatica Jugovic, Jalžić, Prevorčnik and Sket, 2012

Troglocaris (Troglocaris) anophthalmus sontica Jugovic, Jalžić, Prevorčnik and Sket, 2012

Troglocaris (Troglocaris) bosnica Sket et Zakšek, 2009

Troglocaris (Troglocaris) planinensis Birstein, 1948

Troglocaris (Troglocaris) schmidti Dormitzer, 1853

Subgenus Spelaeocaris Matjašič, 1956 - distributed exclusively in the Balkans

Troglocaris (Spelaeocaris) kapelana Sket et Zakšek, 2009

Troglocaris (Spelaeocaris) neglecta Sket et Zakšek, 2009

Troglocaris (Spelaeocaris) prasence Sket et Zakšek, 2009

Troglocaris (Spelaeocaris) pretneri (Matjašič, 1956)

Subgenus Troglocaridella Babić, 1922 - distributed exclusively in the Balkans Troglocaris (Troglocaridella) hercegovinensis (Babić, 1922)

Subgenus Xiphocaridinella Sadowsky, 1930 - exclusively Caucasian group

Troglocaris (Xiphocaridinella) ablaskiri Birstein, 1939

Troglocaris (Xiphocaridinella) fagei Birstein, 1939

Troglocaris (Xiphocaridinella) jusbaschjani Birstein, 1948

Troglocaris (Xiphocaridinella) kutaissiana (Sadowsky, 1930)

Troglocaris (Xiphocaridinella) osterloffi Juzbaš’jan, 1940

Troglocaris (Xiphocaridinella) kumistavi Marin, 2017

The active study of cave shrimps in the Caucasus began in the 1930s-1950s. At the moment, 6 species of the genus Troglocaris (subgenus Xiphocaridinella) are described from the caves from the territory of the southwestern part of Russia, Abkhazia and Western Georgia, which are relicts of the freshwater fauna of the Sarmatian or Pontine seas (basins) (Sadowsky, 1930; Birštein, 1939, 1948; Juzbaš’jan, 1940; Sendra and Reboleira, 2012; Marin and Sokolova, 2014; Marin, 2017). This group is assumed to be much more diverse in the Caucasus than is presently known and many species will be discovered in the nearest future. Shrimps of the genus Troglocaris have been recorded at a depth of more than 2,000 meters in the lower siphon of Krubera Cave in Abkhazia, which at the moment is considered the deepest in the world (Sendra and Reboleira, 2012). To mark species within crustacean genera, including the Troglocaris (Xiphocaridinella) species complex, it is useful to use the mitochondrial cytochrome $\mathrm{c}$ oxidase subunit I gene marker (COI), as one of the most informative markers for population and species-level genetic studies (Avise, 1993). At the same time, data on the Caucasian clade are not numerous and special criteria are needed for recognition of species and genera within this group of atyid cave shrimps.

\section{Material and methods}

This paper presents an attempt to evaluate the genetic diversity on the marker region of subunit I of cytochrome oxidase of mitochondrial DNA (COXI mtDNA) of troglobiotic shrimps of the genus Troglocaris and representatives of the genus from the Caucasus based on available collections and new collected material. For the Caucasian clade freshly collected topotypic material was used, which allowed us to obtain genetic data that had not previously been reported for this genus - Troglocaris (Xiphocaridinella) kutaissiana Sadowsky, 1930 (Tskaltsitela Cave, Western Georgia), Troglocaris (Xiphocaridinella) fagei Birštein, 1939 (New Athon Cave, Abkhazia), Troglocaris (Xiphocaridinella) jusbaschjani Birštein, 1948 (Agura River, Sochi, Russia), Troglocaris (Xiphocaridinella) ablaskiri Birštein, 1939 (Abrskila Cave, Abkhazia) and Troglocaris (Xiphocaridinella) osterloffi Juzbašjjan, 1940 (the Lower Shakuran Cave, Abkhazia) and Troglocaris (Xiphocaridinella) kumistavi Marin, 2017 (Prometheus (Kumistavi) Cave, Western Geor- gia). The name "Troglocaris birsteini Muge, Zueva et Ershov, 2001", proposed for the species reported from Otapa Cave, should be considered as nomen nudum (Franjevic et al., 2010). All collected material is deposited in the collection of the Laboratory of Ecology and Morphology of Marine Invertebrates of the Institute of Ecology and Evolution. A. N. Severtsov RAS (Moscow). Species names and a modern taxonomic position are given according to the international database of the World Register of Marine Species (WoRMS) and the Marine Species Identification Portal.

To resolve the taxonomy of cryptic diversity of species complex fragments of the mitochondrial gene coding for cytochrome oxidase $c$ subunit I (COI) as one of the most popular markers for population genetic studies (Avise, 1994, 2000) were amplified and compared. Total genomic DNA was extracted from pleopods or abdominal muscle tissue using the innuPREP DNA Micro Kit (AnalitikJena, Germany) following the manufacturer's protocol. The mitochondrial marker COI was amplified with the help of «PCR Core» (Isogene Lab., Moscow) using the universal primers LCO1490 (5'-ggtcaacaaatcataaagatattgg-3') and HC02198 (5'-taaacttcagggtgaccaaaaaatca-3') (Folmer et al., 1994). PCR products were performed on amplificator «Tercik DNA Technology» under the following conditions: initial denaturation at $94{ }^{\circ} \mathrm{C}$ for 2 min followed by 40 cycles of $95{ }^{\circ} \mathrm{C}$ for $2 \mathrm{~min}, 59^{\circ} \mathrm{C}$ for $45 \mathrm{~s}$, and $72{ }^{\circ} \mathrm{C}$ for $1.5 \mathrm{~min}$, followed by chain extension at $72{ }^{\circ} \mathrm{C}$ for $7 \mathrm{~min}$. The volume of $20 \mathrm{uL}$ of reaction mixture contained $5 \mathrm{uL}$ of total DNA, $10 \mathrm{uL}$ of PCR Diluent and $2.5 \mathrm{uL}$ of each primer. Synthesis of the full-length fragment was performed at an annealing primer temperature $59^{\circ} \mathrm{C}$ during 45 seconds. The amplification products were separated by using gel electrophoresis of nucleic acids on a $2 \%$ agarose gel in 1xTBE, and then stained and visualized with $0.003 \%$ EtBr using imaging UV software. The resulting PCR products were sequenced in both forward and reverse direction on the basis of "EuroGen" (Moscow, Russia). Uniformity of sequences obtained was performed using the program BioEdit v. 5.0.9. The resulting markers of COXI gene of mtDNA with 598 bp long section were used for further phylogenetic analysis. The received nucleotide alignments of COI gene were used to construct the phylogenetic relations (tree) in MEGA 7.0 using k-nearest neighbor's algorithm (k-NN, Neighbor-Joining method) and Maximum-likelihood algorithm. Uncorrected pairwise genetic distances (p-distance) were calculated based on COI sequences using MEGA 7.0. Data on "molecular clocks" are used according to Zakšek et al. (2006) calculated for Troglocaris s.s. as well as Knowlton et al. (1993) and Knowlton \& Weigt (1998) suggested for shrimps of the genus Alpheus (Crustacea: Decapoda: Alpheidae) as sequence divergence rate of about $1.4-2.4 \%$ per MYA for COXI gene marker.

\section{Results}

All known Caucasian Xiphocaridinella species are strictly restricted to certain karst cave ecosystems showing significant genetic divergence between known species (Table 1), which is usually not less than $5 \%$. At the same time, the interspecies genetic variability within populations is very low (Table 2). Relatively high variability within Troglocaris (Xiphocaridinella) fagei is explained by mixture of three separate populations from the closely spaced New Athon, Habu and Mchishta caves, while variability within population from each of caves is similar to other species, being about 0.003 substitutions per 100 nucleotides.

\section{Table 1}

Uncorrected pairwise genetic (COXI) distances between known Caucasian species of subgenus Xiphocaridinella (asterisk indicates minimum values of p-distances)

\begin{tabular}{llccc}
\hline \multicolumn{1}{c}{ Species } & X. kutaissana & X. kumistavi & X. ablaskiri & X. osterloffi \\
\hline X. kumistavi & $0,058 \pm 0,010^{*}$ & - & - & - \\
X. ablaskiri & $0,112 \pm 0,014$ & $0,099 \pm 0,013$ & - & - \\
X. osterloffi & $0,120 \pm 0,014$ & $0,108 \pm 0,013$ & $0,103 \pm 0,014$ & - \\
X. fagei & $0,120 \pm 0,014$ & $0,107 \pm 0,014$ & $0,106 \pm 0,014$ & $0,100 \pm 0,013$ \\
$X$. jusbachiani & $0,109 \pm 0,014$ & $0,104 \pm 0,015$ & $0,104 \pm 0,015$ & - \\
\hline
\end{tabular}


Table 2

Uncorrected pairwise genetic (COXI) distances within studied populations of known Caucasian species of subgenus Xiphocaridinella (asterisk indicates minimum values of p-distances)

\begin{tabular}{lc}
\hline \multicolumn{1}{c}{ Species } & Uncorrected pairwise genetic \\
\hline Xiphocaridinella fagei & $0,014 \pm 0,003^{*}$ \\
$X$. kutaissana & $0,0006 \pm 0,0006^{*}$ \\
$X$. ablaskiri & $0,003 \pm 0,001$ \\
X. jusbachiani & $0,002 \pm 0,001$ \\
$X$. osterloffi & $0,003 \pm 0,0015$ \\
X. kumistavi & $0,0009 \pm 0,0008^{*}$ \\
\hline
\end{tabular}

Uncorrected pairwise genetic (COXI) distances (p-distances) between subgenera of Troglocaris s.l. (Table 3; Fig. 1) show well supported divergences with p-distances not less than 17-20\%. The division of the subgenus Spelaeocaris and Troglocaridella for the Dinaric group is not justified on the basis of available molecular data. The genetic subdivision between subgenera of Troglocaris s.l is similar to generic level divergence between Galocaris and Troglocaris s.s. (Table 3). The data obtained clearly support the monophylety of Xiphocaridinella and Troglocaris s.s. while Spelaeocaris represents a paraphyletic taxon (Fig. 1).

\section{Discussion}

The genetic subdivision between subgenera of Troglocaris s.l is similar to generic level divergence between Galocaris and Troglo- caris s.s (Table 3). Such phylogenetic relations within Troglocaris are also supported by Sket and Zakšek (2009) based on sequences of cytochrome oxidase subunit I (COI) + 16S rDNA. Thus, subgenera of the genus Troglocaris s.l. should be considered as separate genera. It is possible to use p-distances calculated for COXI gene marker larger than $17 \%$ for generic separation within European Troglocaris-related atyid shrimps and 5\% for separation of cryptic species within Caucasian Xiphocaridinella, which is rather similar to criteria suggested in other groups of decapod crustaceans and invertebrates (see Knowlton et al., 1993; Knowlton and Weigt, 1998; Hebert et al. 2003; Sites and Marshall 2004; Zakšek et al., 2006, 2009; Lefébure et al. 2006; Lushai et al., 2003). Besides, Troglocaris bosnica shows a significant genetic difference (at the level of the separate genus) from the remaining representatives of the genus Troglocaris s.s. (Table 3).

At the same time, the monotypic genus Troglocaridella is separated from the representatives of the genus Spelaeocaris mostly based on the presence of supraorbital spines on the carapace in T. hercegovinensis vs. their absence in Spelaeocaris (after Sket and Zakšek, 2009). Such morphological features are variable within genera (Sket and Zakšek, 2009; Marin and Sokolova, 2014) while generic data (Fig. 1; Table 3) do not allow clear separation of T. hercegovinensis from other representatives of the genus Spelaeocaris and it is presently suggested to synonymize genera Spealeocaris and Troglocaridella of the Dinaric group and further consider the species as Spealeocaris hercegovinensis (Babić, 1922) comb. nov.

\section{Table 3}

Uncorrected pairwise genetic (COXI) distances between subgenera of Troglocaris s.l. and outgroup atyid shrimp genera (asterisk indicates minimum values of p-distances)

\begin{tabular}{|c|c|c|c|c|c|c|c|c|}
\hline Species & Troglocaris & $\begin{array}{l}\text { Troglocaris } \\
\text { bosnica }\end{array}$ & Spealeocaris & Troglocaridella & Xiphocaridella & Atyaephyra & Dugatella & Galocaris \\
\hline Troglocaris bosnica & $0,153 \pm 0,024^{*}$ & - & - & - & - & - & - & - \\
\hline Spealeocaris & $0,217 \pm 0,024$ & $0,222 \pm 0,024$ & - & - & - & - & - & - \\
\hline Troglocaridella & $0,243 \pm 0,024$ & $0,241 \pm 0,025$ & $0,169 \pm 0,024^{*}$ & - & - & - & - & - \\
\hline Xiphocaridella & $0,214 \pm 0,024$ & $0,225 \pm 0,024$ & $0,189 \pm 0,025^{*}$ & $0,207 \pm 0,024$ & - & - & - & - \\
\hline Atyaephyra & $0,265 \pm 0,027$ & $0,261 \pm 0,029$ & $0,295 \pm 0,027$ & $0,322 \pm 0,031$ & $0,275 \pm 0,020$ & - & - & - \\
\hline Dugatella & $0,264 \pm 0,022$ & $0,279 \pm 0,026$ & $0,287 \pm 0,024$ & $0,308 \pm 0,026$ & $0,296 \pm 0,017$ & $0,275 \pm 0,018$ & - & - \\
\hline Galocaris & $0,200 \pm 0,025^{*}$ & $0,213 \pm 0,023$ & $0,276 \pm 0,025$ & $0,295 \pm 0,026$ & $0,255 \pm 0,020$ & $0,257 \pm 0,025$ & $0,260 \pm 0,021$ & - \\
\hline Typhlatya & $0,275 \pm 0,023$ & $0,264 \pm 0,020$ & $0,260 \pm 0,023$ & $0,290 \pm 0,023$ & $0,289 \pm 0,018$ & $0,255 \pm 0,023$ & $0,288 \pm 0,019$ & $0,235 \pm 0,016$ \\
\hline
\end{tabular}

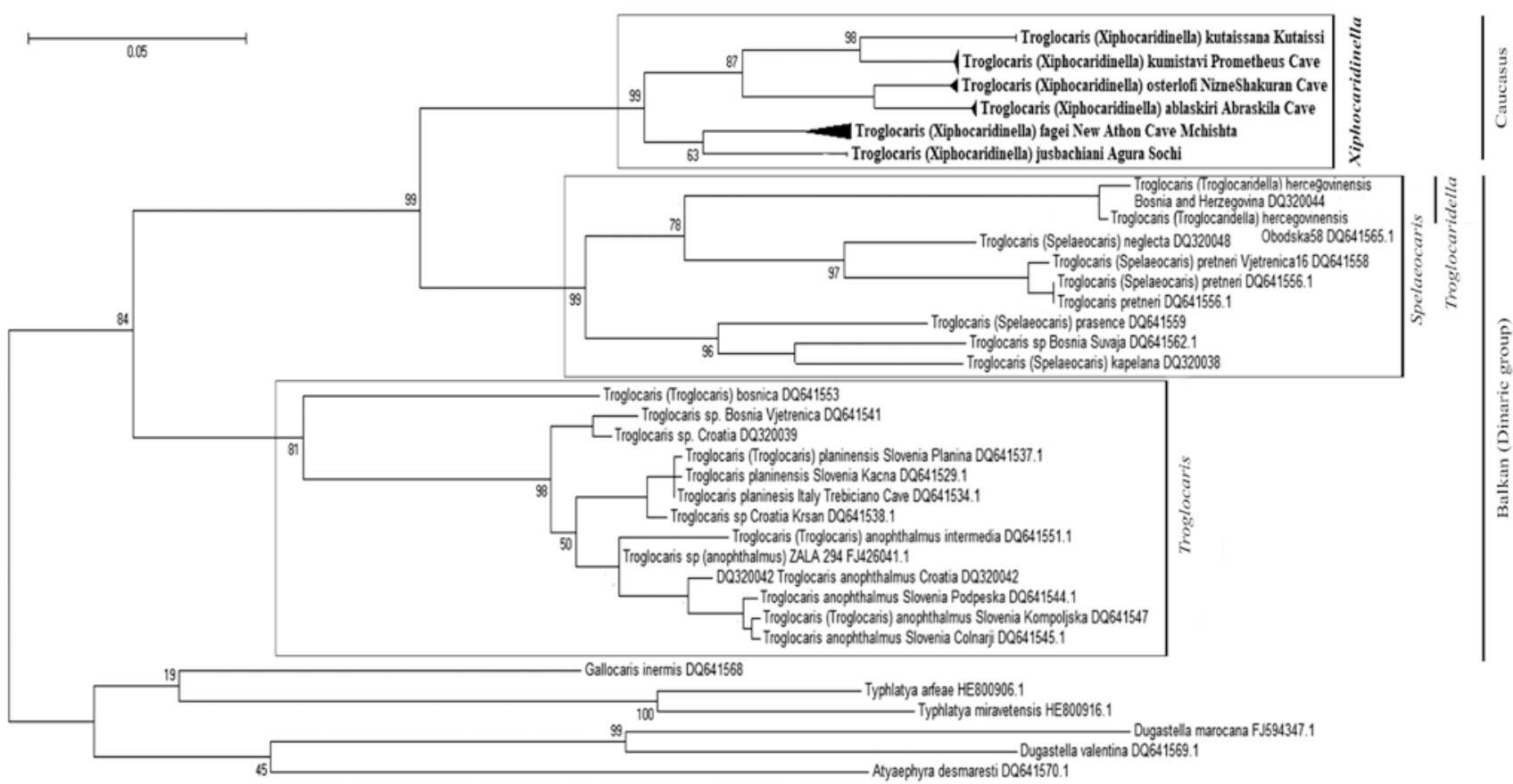

Fig. 1. The evolutionary tree of Troglocaris s. l. based on COXI gene marker obtained using the Maximum-Likelihood method based on the Kimura 2-parameter model 
Similar morphological variability in the armature of the rostrum in the carapace is known from the Caucasian Xiphocaridinella currently including 6 valid species known from the Russian part of the Caucasus (Krasnodar Territory), Abkhazia and Western Georgia. Xiphocaridinella jusbaschjani known exclusively known from the Agura River (Sochi, Russia) shows an extremely short (reduced) unarmed rostrum and the absence of supraorbital or suborbital teeth on the carapace. This has even led to the transfer of the species to the genus Typhlatya (D'UdekemD'Acoz, 1999). Five remaing species of Xiphocaridinella show a varying pattern of armature of the rostrum from unarmed in $X$. fagei (Marin and Sokolova, 2015) to strongly armed dorsally and ventrally in X. kumistavi (Marin, 2017). Anyway, $X$. jusbaschjani strictly belongs to the genus Xiphocaridinella by other morphological features and present genetic data (Table 1; Fig. 1). Thus, the armature of the rostrum and the presence of supraorbital or suborbital teeth on the carapace could not be considered as morphological features of the generic level. Moreover, extreme variations of the length of the rostrum and supraorbital teeth within the genera Troglocaris and Xiphocaridinella and even populations of Troglocaris-related shrimps has been shown (Zakšek et al., 2007; Jugovic et al., 2010, 2011, 2012; Marin, 2017), even suggesting the theory of the influence of predators such as cave salamander Proteus anguinus Laurenti, 1768 (Amphibia: Caudata: Proteidae) (Jugovic et al., 2011). The obtained genetic data clearly support the monophylety of Xiphocaridinella and Troglocaris while Spelaeocaris represent a paraphyletic taxon (Fig. 1).

It is obvious that representatives of modern genera Troglocaris, Spelaeocaris and Xiphocaridinella were descended from a common ancestor which lived in the ancient Sea of Paratethis. The hypothesis of the recent split (about 6-11 million years ago) between the Caucasian and Dinar cave shrimps of the Paratethis relict (Zakšek et al., 2006) supports the idea of a closer relationship between the subgenus Spelaeocaris and Xiphocaridinella than with the Dinaric group, which we also believe is correct on the basis of our research. Besides, it is possible to suggest two separate divergence events between within Dinaric-Caucasian Troglocaris lineages (genera), which occurred about 9-15MYA (ancestors of Troglocaris separated from Spelaeocaris-Xiphocaridinella) and about 8-13MYA when ancestors of Spelaeocaris separated from Troglocaris vs single split about 6-11MYA suggested by Zakšek et al. (2006).

Author is very thankful to Dr. Roman S. Dbar (Institute of Ecology of Academy of Science of Abkhazia) for help during sampling in Abkhazia, to Dr. Pavel Sorokin (A. N. Severtzov Institute of Ecology and Evolution of RAS, Moscow) for help with sequencing and Ilya Turbanov (I. D. Papanin Institute for Biology of Inland Waters of Russian Academy of Sciences, Borok, Russia) for help during sampling in Otap and Abrskil caves and collecting the specimens in Samschitovaya Cave.

\section{References}

Babic, K. (1922). Über die drei Atyiden aus Jugoslavien. Glasnik der Kroatischen Naturwissenschaftlichen Gesellschaft, Zagreb, 34, 300-306.

Birštein, Y. A. (1939). O peshernysh krevetkah Abhazii [About cave shrimps of Abkhazia]. Zoologichesky Zhurnal, 18, 960-974 (in Russian).

Birštein, Y. A. (1948). O nahozdenii pesherinoy krevetki Troglocaris v gruntovyh vodah Abkhazii b svazannye s etim voprosy [The occurrence of the cave shrimp Troglocaris in underground water of Mazesta and related problems]. Byulleten' Moskovskogo Obshchestva Ispytatelei Prirody, Otdel Biologicheskii, 53, 3-10 (in Russian).

D’Udekemd'Acoz, C. (1999). Inventaireet distribution des crustacés décapodes de l'Atlantiquenord-oriental, de la Méditerranée et des ea ux continentale sadjacentes au nord de $25 \mathrm{~N}$. Patrimoines Naturels, 40, 1-383.

De Grave, S., \& Fransen, C. H. J. M. (2011). Carideorum catalogus: The recent species of the dendrobranchiate, stenopodidean, procarididean and caridean shrimps (Crustacea: Decapoda). Zoologische Mededelingen, 85(9), 195-589.

Franjević, D., Kalafatić, M., Kerovec, M., \& Gottstein, S. (2010). Phylogeny of cave-dwelling atyid shrimp Troglocaris in the Dinaric Karst based on sequences of three mitochondrial genes. Periodicum Biologorum, 112(2), 159-166.
Hebert, P. D. N., Cywinska, A., Ball, S. L., \& De Waard, J. R. (2003). Biological identifications through DNA barcodes. Proceedings of the Royal Society of London B, 270, 313-322.

Jaume, D., \& Bréhier, F. (2005). A new species of Typhlatya (Crustacea: Decapoda: Atyidae) from anchialine caves on the French Mediterranean coast. Zoological Journal of the Linnean Society, 144, 387-414.

Jugovic, J., Jalžić, B., Prevorčnik, S., \& Sket, B. (2012). Cave shrimps Troglocaris s. str. (Dormitzer, 1853), taxonomic revision and description of new taxa after phylogenetic and morphometric studies. Zootaxa, 3421, 1-31.

Jugovic, J., Prevorčnik, S., Aljančič, G., \& Sket, B. (2010). The atyid shrimp (Crustacea: Decapoda: Atyidae) rostrum: Phylogeny versus adaptation, taxonomy versus trophic ecology. Journal of Natural History, 44(41-42), 2509-2533.

Jugovic, J., Prevorčnik, S., Blejec, A., \& Sket, B. (2011). Morphological differentiation in the cave shrimps Troglocaris (Crustacea: Decapoda: Atyidae) of the Dinaric karst - A consequence of geographical isolation or adaptation? Journal of Zoological Systematic and Evolutionary Researches, 49(3), 185-195.

Juzbaš’jan, S. M. (1940). O Shakuranskoy pesernoy krevetke [On a cave shrimp from Shakuran]. Trudy Biologiceskoj Stancii Narkomprosa Gruzinskoj SSR, 1, 73-86 (in Russian).

Knowlton, N., \& Weigt, L. A. (1998). New dates and new rates for divergence across the Isthmus of Panama. Proceedings of the Royal Society of London. Series B, 265, 2257-2263.

Knowlton, N., Weight, L. A., Solórzano, L. A., Mills, D. K., \& Bermingham, E. (1993). Divergence in proteins, mitochondrial DNA and reproductive compatibility across the Isthmus of Panama. Science, 260(5114), 1629-1632.

Lefébure, T., Douady, C. J., Gouy, M., \& Gibert, J. (2006). Relationship between morphological taxonomy and molecular divergence within Crustacea: Proposal of a molecular threshold to help species delimitation. Molecular Phylogenetics and Evolution, 40(2), 435-447.

Lushai, G., Smith, D. A. S., Goulson, D., Allen, J. A., \& Maclean, N. (2003). Mitochondrial DNA clocks and the phylogeny of Danaus butterflies. Insect Science and its Application, 2, 309-315.

Marin, I. (2017). Troglocaris (Xiphocaridinella) kumistavi sp. nov., a new species of stygobiotic atyid shrimp (Crustacea: Decapoda: Atyidae) from Kumistavi Cave, Imereti, Western Georgia, Caucasus. Zootaxa, 4311(4), 576-588.

Marin, I. N. (2015). Atlas of decapod crustaceans of Russia. KMK Scientific Press, Moscow.

Marin, I. N., \& Sinelnikov, S. Y. (2017). Preliminary data on larval development of Caucasian cave-dwelling shrimp Troglocaris (Xiphocaridinella) kumistavi Marin, 2017 (Crustacea: Decapoda: Atyidae). Arthropoda Selecta, 26(4), 297-302.

Marin, I. N., \& Turbanov, I. S. (2015). Peshernye krevetki roda Troglocaris Dormitzer, 1853 (Crustacea: Decapoda: Atyidae): Raznoobrazie, ecologiya, proiskhozdenie [Cave shrimps of the genus Troglocaris Dormitzer, 1853 (Crustacea: Decapoda: Atyidae): Diversity, ecology, origin]. In: Turbanov, I. S., Marin, I. N., \& Gongalsky, K. B. (Eds.). Abstracts of the Youth Conference "Biospeleology of the Caucasus and other regions of Russia" (IPEE RAS, Moscow, December, 3-4, 2015). Kostroma Printing House, Kostroma. pp. 36-41.

Marin, I., \& Sokolova, A. (2014). Redescription of the stygobiotic shrimp Troglocaris (Xiphocaridinella) jusbaschjani Birštein, 1948 (Decapoda: Caridea: Atyidae) from Agura River, Sochi, Russia, with remarks on other representatives of the genus from Caucasus. Zootaxa, 3754(3), 277-298.

Matjasic, J. (1956). Ein neuer Höhlen decapods e aus Jugoslawien. Zoologischer Anzeiger, 157, 65-68.

Sadowsky, A. A. (1930). Xiphocaridinella kutaissiana nov. gen. et sp. (fam. Atyidae) iz podzemnoi peshchery pod Kutaisom [Xiphocaridinella kutaissiana nov. gen. et sp. (fam. Atyidae) from subterranean cave near Kutaisi]. Zakavkazskij Kraevedstenny Sbornik Naučnoissledovatel'nogo Kraevedstvenogo Kabineta Universiteta Tiflis, 1, 93-104 (in Russian).

Sanz, S., \& Platvoet, D. (1995). New perspectives on the evolution of the genus Typhlatya (Crustacea, Decapoda): First record of a cavemicolous atyid in the Iberian Peninsula, Typhlatya miravetensis n. sp. Contributions to Zoology, 65, 79-99.

Sendra, A., \& Reboleira, A. S. P. S. (2012). The world's deepest subterranean community - Krubera-Voronja Cave (Western Caucasus). International Journal of Speleology, 42(2), 221-230.

Sites, J. W., \& Marshall, J. C. (2004). Operational criteria for delimiting species. Annual Review of Ecology, Evolution, and Systematics, 35, 199-227.

Sket, B. (2003). Distribution of Proteus (Amphibia: Urodela: Proteidae) and its possible explanation. Journal of Biogeography, 24(3), 263-280.

Sket, B., \& Zakšek, V. (2009). European cave shrimp species (Decapoda: Caridea: Atyidae), redefined after a phylogenetic study; redefinition of some taxa, a new genus and four new Troglocaris species. Zoological Journal of the Linnean Society, 155(4), 786-818. 
Turbanov, I. S., \& Marin, I. N. (2015). Typhlogammaridae (Crustacea: Amphipoda) - Novoe semeistvo stigobontnyh amphipod dla fauny Rossii is podzemnyh vod Krasnodaskogo kraya [Typhlogammaridae (Crustacea: Amphipoda) - A new family of stygobiotic amphipods for the Russian fauna in groundwater of the Krasnodar Territory]. In: Turbanov, I. S., Marin, I. N., \& Gongalsky, K. B. (Eds.). Abstracts of the Youth Conference "Biospeleology of the Caucasus and other regions of Russia" (IPEE RAS, Moscow, December, 3-4, 2015). Kostroma Printing House, Kostroma. pp. 87-89.

Turbanov, I. S., Palatov, D. M., \& Golovatch, S. I. (2016). The state of the art of biospeleology in Russia and other countries of the former Soviet Union: A review of the cave (endogean) invertebrate fauna. 1. Introduction. Crustacea. Entomological Review, 96, 926-963.

Zakšek, V., Sket, B., \& Trontelj, P. (2006). Phylogeny of the cave shrimp Troglocaris: Evidence of a young connection between Balkans and Caucasus. Molecular Phylogenetics and Evolution, 42, 223-235.

Zakšek, V., Sket, B., Gottstein, S., Franjevic, D., \& Trontelj, P. (2009). The limits of cryptic diversity in groundwater: Phylogeography of the cave shrimp Troglocaris anophthalmus (Crustacea: Decapoda: Atyidae). Molecular Ecology, 18, 931-946. 